\title{
EFFECTS OF A SINGLE INTRAMUSCULAR INJECTION OF VITAMIN K ON THE HEMATOLOGY, SERUM BIOCHEMISTRY AND COAGULATION PARAMETERS IN HEALTHY ADULT DAIRY COWS
}

\author{
Zuhair Bani Ismail, Myassar O. Alekish, Mofleh S. Awawdeh, Issa Olymat \\ Faculty of Veterinary Medicine, Jordan University of Science and Technology, \\ Irbid 22110 - Jordan
}

Received 25 January 2016; Received in revised form 19 March 2016; Accepted 13 April 2016

\begin{abstract}
Vitamin $\mathrm{K}_{1}$ is commonly administered to dairy cattle suffering from uncontrollable hemorrhage and to cattle with known deficiency of vitamin $\mathrm{K}$ dependent coagulation factors. However, a review of recent literature concludes the absence of available information regarding the safety and effects of this drug in dairy cattle. Therefore, this study was carried out to evaluate the safety and effects of a single intramuscular injection of vitamin $K_{1}(2.5 \mathrm{mg} / \mathrm{kg})$ on various clinical, hematological, serum biochemical and coagulation parameters in adult Holstein dairy cows. Six adult Holstein dairy cows were injected a single intramuscular dose of vitamin $\mathrm{K}_{1}$. Cows were then clinically monitored for 24 hours after drug administration for any abnormal behavioral activities. The heart rate, respiration rate, rectal temperature, and rumen motility were also reported before and at each follow-up check point after administration of the drug. Whole blood samples were collected before and again at 15, 30, 60 , and 120 minutes and at 24 hours after drug administration. Hematology and serum biochemistry parameters were evaluated to detect any systemic effects. Selected coagulation parameters including the activated partial thromboplastine time (APTT), prothrombin time (PT), thrombin time (TT), D-dimers, platelets count, and fibrinogen concentrations were determined to evaluate the effect of the drug on coagulation mechanisms. There were no abnormal clinical, pathological, or behavioral activities associated with the drug administration in all cows. In the coagulation profile, there was a significant increase in platelets counts starting from 15 minutes after administration and throughout the observation period. Other coagulation parameters were not significantly changed.
\end{abstract}

Key words: hemorrhage, anemia, shock, coagulant, vitamin $\mathrm{K}_{1}$

\section{INTRODUCTION}

Vitamin K (Phytonadione) is widely used in dairy cattle practices as an emergency treatment of uncontrollable hemorrhage $(1,2)$. In cattle, there are no scientific research on safety and efficacy of the drug. It is believed that vitamin $\mathrm{K}$ is important for the synthesis and activation of coagulation factor II (prothrombin), factor VII (proconvertin), IX (christmas factor) and factor $X$ (3). Clinically, other common indications of

Corresponding author: Dr. Zuhair Bani Ismail, Diplomate ABVP E-mail address: zuhair72@just.edu.jo

Present address: Faculty of Veterinary Medicine,

Jordan University of Science and Technology

Irbid 22110 - Jordan

Phone: ++00962796654331

Copyright: (C) 2016 Ismail Z.B. This is an open-access article published under the terms of the Creative Commons Attribution License which permits unrestricted use, distribution, and reproduction in any medium, provided the original author and source are credited.

Competing Interests: The authors have declared that no competing interests exist.

Available Online First: 16 April 2016

Published on: 15 October 2016

http://dx.doi.org/10.1515/macvetrev-2016-0082 the use of vitamin $\mathrm{K}$ in dairy cattle include cases suffering from coagulation disorders caused by vitamin $\mathrm{K}$ deficiency or interference with vitamin $\mathrm{K}$ activity, hypoprothrombinemia induced by ingestion of anticoagulant rodenticides, and hypoprothrombinemia caused by consumption of bishydroxycoumarin found in spoiled and moldy sweet clover (3).

Although the mechanism by which vitamin $\mathrm{K}_{1}$ is effective in cases affected with bleeding disorders due to, for example, moldy sweet clover toxicity (dicoumarol), its mechanism and effects in normal cattle and in cattle with none specific causes of bleeding are not fully elucidated yet. It has been reported that in cattle fed moldy sweet clover, levels of prothrombin time returned to normal within 24 hours after a single injection of vitamin $\mathrm{K}_{1}$ at $1.1-3.3 \mathrm{mg} / \mathrm{kg}$ intramuscularly $(1,2)$. Therefore, this study was performed to evaluate the clinical, hematological and serum biochemical effects associated with a single intramuscular injection of vitamin $K_{1}$ at $2.5 \mathrm{mg} / \mathrm{kg}$ to normal Holstein dairy 
cattle. In addition, effects of vitamin $\mathrm{K}_{1}$ on various clotting times and other coagulation parameters were assessed.

\section{MATERIAL AND METHODS}

\section{Animals}

The procedures performed in this study were approved by the Jordan University of Science and Technology Animal Care and Use Committee. Six healthy adult (2-4 years of age) Holstein dairy cows were used in this study. Prior to the start of the study, the health status of each animal was determined by performing a general physical examination, complete blood cell count (CBC), and serum biochemical prfile. Only healthy cows were used in the study.

\section{Drug administration and clinical monitoring}

Each cow was administered single intramuscular injection of vitamin $\mathrm{K}_{1}$ (Cenavisa, Spain) at a dose rate of $2.5 \mathrm{mg} / \mathrm{kg}$. Drug safety was evaluated by monitoring the rectal temperature using an electrical thermometer inserted into the rectum for 2 minutes; the heart rate by listening to the heart beats using a stethoscope for 1 minute; the respiratory rate by counting the number of chest excursion in 1 minute; the capillary refill time by finger pressing on the vulvar mucosa; the rumen motility by listening and counting rumen motility sounds in 3 minutes using a stethoscope; and behavioral changes (i.e., salivation, urination, defecation, trembling, etc.) by observation immediately after administration and for 24 hours after injection.

\section{Laboratory evaluation}

Whole blood samples were collected in plain tubes, EDTA, and Citrate-containing tubes and were analyzed within 2 hours after collection. Samples were collected before drug administration (Time 0), and at 15, 30, 60, and 120 minutes and
24 hours after administration via vein puncture from the jugular vein from each animal. Hematology and serum biochemical analyses were determined using previously reported methods (4). Parameters investigated were: total white blood cell count (WBC), red blood cell count (RBC), platelets counts, hemoglobin concentration $(\mathrm{Hb})$, packed cell volume (PCV), mean corpuscular volume (MCV), mean corpuscular hemoglobin concentration (MCHC), and fibrinogen concentration.

After centrifugation of clotted whole blood at $1500 \mathrm{~g}$ for 10 minutes, serum was analyzed to determine total protein, blood urea nitrogen, creatinine, aspartate aminotransferase (AST), alanine aminotransferase (ALT), alkaline phosphatase (ALP), calcium, sodium, chloride, and potassium. Whole blood samples in Citrate-containing tubes were used to determine activated partial thromboplastin time [APTT] (STA- C.K. Prest, Stago, France), prothrombin time [PT] (Néoplastine CI Plus, Stago France), thrombin time [TT](STA -Thrombin, Stago, France), D-Dimers (D-Di Test, Stago, France) using commercially available kits according to manufacturers' recommendations.

\section{Statistical Analysis}

Data was presented as mean \pm standard error (SE). Repeated measure analysis of each of the evaluated variables was performed using GLM repeated measures. Post-hoc pairwise comparisons were performed using Bonferroni test. Differences were considered statistically significant if the $\mathrm{P} \leq 0.05$. The analysis was conducted using statistical software (SPSS, Version 19.0, SPSS Inc, Chicago, USA).

\section{RESULTS}

All cows tolerated well the intramuscular injection of $2.5 \mathrm{mg} / \mathrm{kg}$ vitamin $\mathrm{K}_{1}$. The heart rate, respiration rate, rectal temperature and rumen

Table 1. Means \pm SE for certain hematology parameters in healthy adult dairy cows before and after administration of vitamin K1 intramuscularly

\begin{tabular}{|c|c|c|c|c|c|c|}
\hline \multirow{2}{*}{ Parameter } & \multicolumn{5}{|c|}{ Time (minutes) } & \multirow[t]{2}{*}{24 hours } \\
\hline & Pre (T0) & 15 & 30 & 60 & 120 & \\
\hline WBC $\left(\times 10^{3}\right.$ cells $\left./ \mu \mathrm{l}\right)$ & $11 \pm 1$ & $10 \pm 1$ & $10 \pm 1$ & $10 \pm 1$ & $11 \pm 1$ & $16 \pm 1$ \\
\hline RBC $\left(\times 10^{6}\right.$ cells $\left./ \mu \mathrm{l}\right)$ & $7.0 \pm 0.4$ & $6.0 \pm 0.4$ & $6.0 \pm 0.4$ & $7.0 \pm 0.4$ & $7.0 \pm 0.4$ & $6.0 \pm 0.4$ \\
\hline HB $(g / d l)$ & $11 \pm 3$ & $9 \pm 3$ & $9 \pm 3$ & $10 \pm 3$ & $10 \pm 3$ & $10 \pm 3$ \\
\hline PCV\% & $32 \pm 1$ & $28 \pm 1$ & $28 \pm 1$ & $31 \pm 1$ & $31 \pm 1$ & $29 \pm 1$ \\
\hline $\operatorname{MCV}(\mathbf{f l})$ & $44 \pm 1$ & $44 \pm 1$ & $44 \pm 1$ & $42 \pm 1$ & $44 \pm 1$ & $44 \pm 1$ \\
\hline MCH( pg) & $15 \pm 5$ & $15 \pm 6$ & $15 \pm 5$ & $14 \pm 6$ & $15 \pm 5$ & $15 \pm 5$ \\
\hline MCHC (g/dl) & $34 \pm 12$ & $33 \pm 13$ & $34 \pm 12$ & $34 \pm 13$ & $34 \pm 12$ & $35 \pm 12$ \\
\hline
\end{tabular}

WBC- white blood cell count, RBC- red blood cell count, Hb- hemoglobin concentration, PCV- packed cell volume, MCV- mean corpuscular volume, MCHC- mean corpuscular hemoglobin concentration 
Effect of vitamin $\mathrm{K}$ on hematology, biochemistry and coagulation in healthy dairy cows

Table 2. Means \pm SE for certain blood biochemistry parameters in healthy adult dairy cows before and after administration of vitamin $\mathrm{K} 1$ intramuscularly

\begin{tabular}{lllllll}
\hline \multirow{2}{*}{ Parameter } & \multicolumn{5}{c}{ Time (minutes) } & \multirow{2}{*}{ 24 hours } \\
\cline { 2 - 6 } & Pre (T0) & $\mathbf{1 5}$ & $\mathbf{3 0}$ & $\mathbf{6 0}$ & $\mathbf{1 2 0}$ & \\
\cline { 1 - 5 } AST (U/L) & $95 \pm 4$ & $90 \pm 4$ & $92 \pm 4$ & $96 \pm 4$ & $88 \pm 4$ & $87 \pm 4$ \\
ALT (U/L) & $80.0 \pm 3.6$ & $75.0 \pm 3.6$ & $88.0 \pm 3.6$ & $68.0 \pm 3.6$ & $70.0 \pm 3.6$ & $80.0 \pm 3.6$ \\
ALP (U/L) & $100 \pm 17$ & $97 \pm 17$ & $95 \pm 17$ & $79 \pm 17$ & $86 \pm 17$ & $81 \pm 17$ \\
Total protein (g/L) & $84.0 \pm 1.5$ & $83.0 \pm 1.5$ & $83.0 \pm 1.5$ & $83.0 \pm 1.5$ & $83.0 \pm 1.5$ & $83.0 \pm 1.5$ \\
BUN (mmol/L) & $4.0 \pm 1.6$ & $3.6 \pm 1.3$ & $4.5 \pm 1.3$ & $3.8 \pm 1.6$ & $3.3 \pm 1.3$ & $3.7 \pm 1.6$ \\
Creatinine ( $\boldsymbol{\mu m o l} / \mathbf{L})$ & $66.0 \pm 0.1$ & $64.0 \pm 0.1$ & $64.0 \pm 0.1$ & $60.0 \pm 0.1$ & $64.0 \pm 0.1$ & $56.0 \pm 0.1$ \\
Calcium (mmol/L) & $3.5 \pm 0.2$ & $3.3 \pm 0.2$ & $3.5 \pm 0.2$ & $3.8 \pm 0.2$ & $3.8 \pm 0.2$ & $3.7 \pm 0.2$ \\
Sodium (mmol/L) & $141.0 \pm 1.6$ & $142.0 \pm 1.6$ & $144.0 \pm 1.6$ & $146.0 \pm 1.6$ & $146.0 \pm 1.6$ & $141.0 \pm 1.6$ \\
Chloride (mmol/L) & $102.0 \pm 3.9$ & $103.3 \pm 3.9$ & $104.0 \pm 3.9$ & $104.0 \pm 3.9$ & $103.0 \pm 3.9$ & $104.0 \pm 3.9$ \\
Potassium (mmol/L) & $4.5 \pm 1.4$ & $4.5 \pm 1.4$ & $4.0 \pm 1.4$ & $4.0 \pm 1.4$ & $3.9 \pm 1.4$ & $4 \pm 1.4$ \\
\hline
\end{tabular}

AST- aspartate aminotransferase, ALT-alanine aminotransferase, ALP- alkaline phosphatase, BUN- blood urea nitrogen

motility patterns remained within normal limits during the observation period (24 hours). There were no abnormal behavioral activities associated with the injection of the drug. In the hematology and serum biochemistry profiles, all values were within normal range (Tables 1, 2).

In the clotting profile, the only significant effect was an increased platelets counts starting from 15 minutes after administration that remained high at 24 hours after administration (Table 3 ). specific systemic toxic effects $(1,2)$. Unfortunately, clinical efficacy and safety studies concerning this commonly used drug in cattle practice are currently lacking. In this study, the administration of vitamin $\mathrm{K}_{1}$ to normal adult dairy cows at therapeutic dose $(2.5 \mathrm{mg} / \mathrm{kg})$ resulted in a significant increase in platelets numbers. It has been reported that vitamin $\mathrm{K}$ administration quantitatively improves platelet functions, but no effects were seen concerning other clotting factor functions in normal subjects (6).

Table 3. Means \pm SE of blood clotting factors and platelets in healthy adult dairy cows before and after administration of vitamin K1 intramuscularly

\begin{tabular}{|c|c|c|c|c|c|c|}
\hline \multirow{2}{*}{ Parameter } & \multicolumn{5}{|c|}{ Time (minutes) } & \multirow{2}{*}{24 hours } \\
\hline & Pre (T0) & 15 & 30 & 60 & 120 & \\
\hline Platelet $\left(\times 10^{3}\right.$ cells $\left./ \mu \mathrm{L}\right)$ & $298 \pm 34^{\mathrm{a}}$ & $349 \pm 37^{a ̀}$ & $385 \pm 34^{a ̀}$ & $439 \pm 37^{\mathrm{à}}$ & $468 \pm 34^{a ̀}$ & $427 \pm 34^{\text {à }}$ \\
\hline PT (seconds) & $25 \pm 9$ & $25 \pm 9$ & $25 \pm 9$ & $26 \pm 9$ & $26 \pm 9$ & $26 \pm 9$ \\
\hline APTT (seconds) & $53 \pm 4$ & $56 \pm 4$ & $55 \pm 4$ & $51 \pm 4$ & $47 \pm 4$ & $52 \pm 4$ \\
\hline TT (seconds) & $32 \pm 1$ & $32 \pm 1$ & $32 \pm 1$ & $32 \pm 1$ & $33 \pm 1$ & $32 \pm 1$ \\
\hline D-dimer (ng/ml) & $<0.5$ & $<0.5$ & $<0.5$ & $<0.5$ & $<0.5$ & $<0.5$ \\
\hline Fibrinogen (mg/dL) & $533 \pm 33$ & $533 \pm 33$ & $533 \pm 33$ & $533 \pm 33$ & $533 \pm 33$ & $550 \pm 33$ \\
\hline
\end{tabular}

Values in the same row with different uppercase superscripts are significantly different at $\mathrm{P}<0.05$

PT- prothrombin time, APTT- activated partial thromboplastin time, TT- thrombin time

\section{DISCUSSION}

Injected cattle suffering from bleeding due to unspecified origin such as bloody milk, and hemorrhagic diathesis with vitamin $\mathrm{K}_{1}$ is a common practice $(4,5)$. Although, clinical improvement of such animals after drug administration is difficult to assess, other unwanted or undesirable side effects can occur such as hypersensitivity reactions or non-
Vitamin $K_{1}$ is naturally synthesized by ruminal and intestinal bacteria and, in most cases, the synthesized amounts meet daily requirements of cows. However, supplemental $\mathrm{K}_{1}$ is needed in special cases (i.e., cows fed moldy sweet clover) (7). Vitamin K controls the synthesis of a group of coagulation factors such as factor II (prothrombin), VII, IX, and X in the liver. Other coagulation factors that are dependent on vitamin $\mathrm{K}$ are protein $\mathrm{C}, \mathrm{S}$, and $\mathrm{Z}$. Protein $\mathrm{C}$ and $\mathrm{S}$ are anticoagulants $(1,2)$. 


\section{CONCLUSION}

Results of this study indicate that vitamin $\mathrm{K}_{1}$ administration to dairy cattle is safe and may result in some beneficial therapeutic effects in cases with minor bleeding tendencies such as vitamin $\mathrm{K}$ deficiency associated hemorrhagic diathesis or in cases with mild bleeding due to external trauma such as bloody milk.

\section{ACKNOWLEDGEMENTS}

The authors would like to thank the Deanship of Research at Jordan University of Science and Technology for sponsoring this project. We also would like to thank the staff of the University Agricultural Research Farm for their valuable assistance.

\section{REFERENCES}

1. Radostits, O.M., Gay, C.C., Hinchcliff, K.W., Constable, P.D. (Eds.) (2007). Veterinary Medicine, A Textbook of the Diseases of Cattle, Horses, Sheep, Pigs, and Goats. $10^{\text {th }}$ edition. London: Sounders Company.

2. Divers, T.J., Peek, S.F. (Eds.) (2008). Rebhun's Diseases of Dairy Cattle. $2^{\text {nd }}$ edition. Missouri: WB Saunders.
3. Haskell, S.R., Payne, M., Webb, A., Riviere, J., Craigmill, A. (2005). Antidotes in food animal practice. Am. Vet. Med. Assoc. J. 226, 484-487. PMid:15786990

http://dx.doi.org/10.2460/javma.2005.226.884

4. Thrall, M.A. (Ed.) (2004). Veterinary hematology and clinical chemistry. Pennsylvania: Lippincott Williams \& Wilkins

5. Weiss, B. (2005). Update on vitamin nutrition of dairy cows. Rum. Health and Nutr. Conf. at Syracuse, NY and New England Dairy Feed Conference, West Lebanon, NH.

6. Jandrey, K.E. (2012). Assessment of platelet function. J. Vet. Emerg. Crit. Care 22, 81-98. http://dx.doi.org/10.1111/j.1476-4431.2011.00707.x PMid:23016745

7. Weiss, B., Ferreira, G. (2006). Are your cows getting the vitamins they need? WCDS Advances Dairy Technol. 18, 249-259. 